\title{
Nephroma orvoi (Nephromatoideae, Peltigeraceae) - a new lichen species for Russia
}

\author{
G. P. Urbanavichus ${ }^{1 *}$, I. N. Urbanavichene ${ }^{2}$ \\ ${ }^{1}$ Institute of North Industrial Ecology Problems, Kola Science Centre RAS, Akademgorodok, 14a, Apatity, 184209, Murmansk \\ Region, Russian Federation.E-mail: g.urban@mail.ru; ORCID iD: https://orcid.org/0000-0003-3222-5151 \\ ${ }^{2}$ Komarov Botanical Institute RAS, Prof. Popova Str. 2, 197376, St Petersburg, Russian Federation \\ E-mail: urbanavichene@gmail.com; ORCID iD: https://orcid.org/0000-0002-5492-5215 \\ *Corresponding author
}

Keywords: distribution, floristic finding, Murmansk Region, Scandinavia.

Summary. The lichen species Nephroma orvoi is reported as new to Russia from two localities in Murmansk Region. Description and colour illustrations of the material studied are provided. The species was previously known from Norway, Sweden, Finland, Switzerland, Canada (Alberta and British Columbia), USA (Washington), and Greenland. In Russia, it grows on rock outcrops in open habitat along the shore of a Paz River (Pasvik Nature Reserve) and in the bed of a small unnamed stream (neighborhood of Fedorova Tundra Mt.). The specimens were identified by the morphology (mostly laminal, brown, corticate soredia; faveolate, wrinkle-ridged lobes; lower side with short pseudotomentum in middle and inner part) and the identification was confirmed by lichen substances (a series of specific triterpenoids).

\section{Nephroma orvoi (Nephromatoideae, Peltigeraceae) - новый для России вид лишайника}

\author{
Г. П. Урбанавичюс ${ }^{1}$, И. Н. Урбанавичене² \\ ${ }^{1}$ Институт проблем промышленной экологии Севера Кольского научного иеентра РАН, Академический \\ городок, 14a, г. Апатиты, Мурманская область, 184209, Россия \\ ${ }^{2}$ Ботанический институт им. В. Л. Комарова РАН, ул. Проф. Попова, 2, г. Санкт-Петербург, 197376, Россия
}

Ключевые слова: Мурманская область, распространение, Скандинавия, флористическая находка.

Aннотация. Вид Nephroma orvoi приводится впервые для лихенофлоры России из двух местонахождений в Мурманской области. Представлены описание и цветные иллюстрации изучаемого материала. Ранее вид был известен из Норвегии, Швеции, Финляндии, Швейцарии, Канады (Альберта и Британская Колумбия), США (Вашингтон) и Гренландии. В России N. orvoi растет на обнажениях горных пород в открытых местообитаниях вдоль берега реки Паз (государственный природный заповедник «Пасвик») и в русле небольшого безымянного ручья (окрестности горы Федорова тундра). Экземпляры идентифицировали по морфологии (преимущественно поверхностные, коричневые, почти покрытые корой соредии; ямчатые, складчато-морщинистые лопасти; нижняя сторона с коротким псевдотоментумом в средней и внутренней части), также идентификация подтверждена набором лишайниковых веществ (серия специфических тритерпеноидов). 


\section{Introduction}

Nephroma orvoi Timdal et al. was recently described from the Finnmark, Norway and also recorded from many countries - Sweden, Finland, Switzerland, Canada (Alberta and British Columbia), USA (Washington), and Greenland (Timdal et al., 2020). Earlier, in the Nordic Lichen Flora, Vitikainen (2007) reported two chemotypes of Nephroma parile (Ach.) Ach. in the study area and referred to them as chemotypes I (dolichorrhizin, zeorin, hopane-15 $\alpha, 22$-diol) and II (peltidactylin, zeorin, hopane-7 $\beta, 22$-diol and hopane- $6 \alpha, 7 \beta, 22-$ triol). Vitikainen (2007) stated that the taxonomic status of chemotype II should be further studied as it is characterized by soredia tending to be dark, corticate, and concentrated to ridges of the reticulate upper surface, and by the lower surface being covered by short blackish tomentum. And recently, in 2020, Norwegian and Swedish lichenologists have been studied specimens of the Nephroma parile species complex, that may be worthy of recognition at species level. Using phylogenetic analysis of the fungal DNA-barcode marker (ITS) in combination with studies of morphology and chemistry, they discovered two distinct lineages in the $N$. parile species complex. For the strongly supported clade that corresponds to chemotype II, they described the new species Nephroma orvoi (Timdal et al., 2020).

\section{Material and Methods}

This species was first observed by the first author in the field in 2014 in Pasvik Nature Reserve. Then it was identified as Nephroma parile but with unusual brown, insidious soredia. In the current summer 2021, this species was found by the first author in large numbers during the exploration of the surrounding area of the Fedorova Tundra Mt. in the bed of a small unnamed stream (Fig. 1). Morphological characters were examined by standard microscopic techniques. Lichen substances were studied by a high performance thin-layer chromatography (HPTLC) in solvent system C (Orange et al., 2001) in the laboratory lichenology and bryology of the Komarov Botanical Institute.

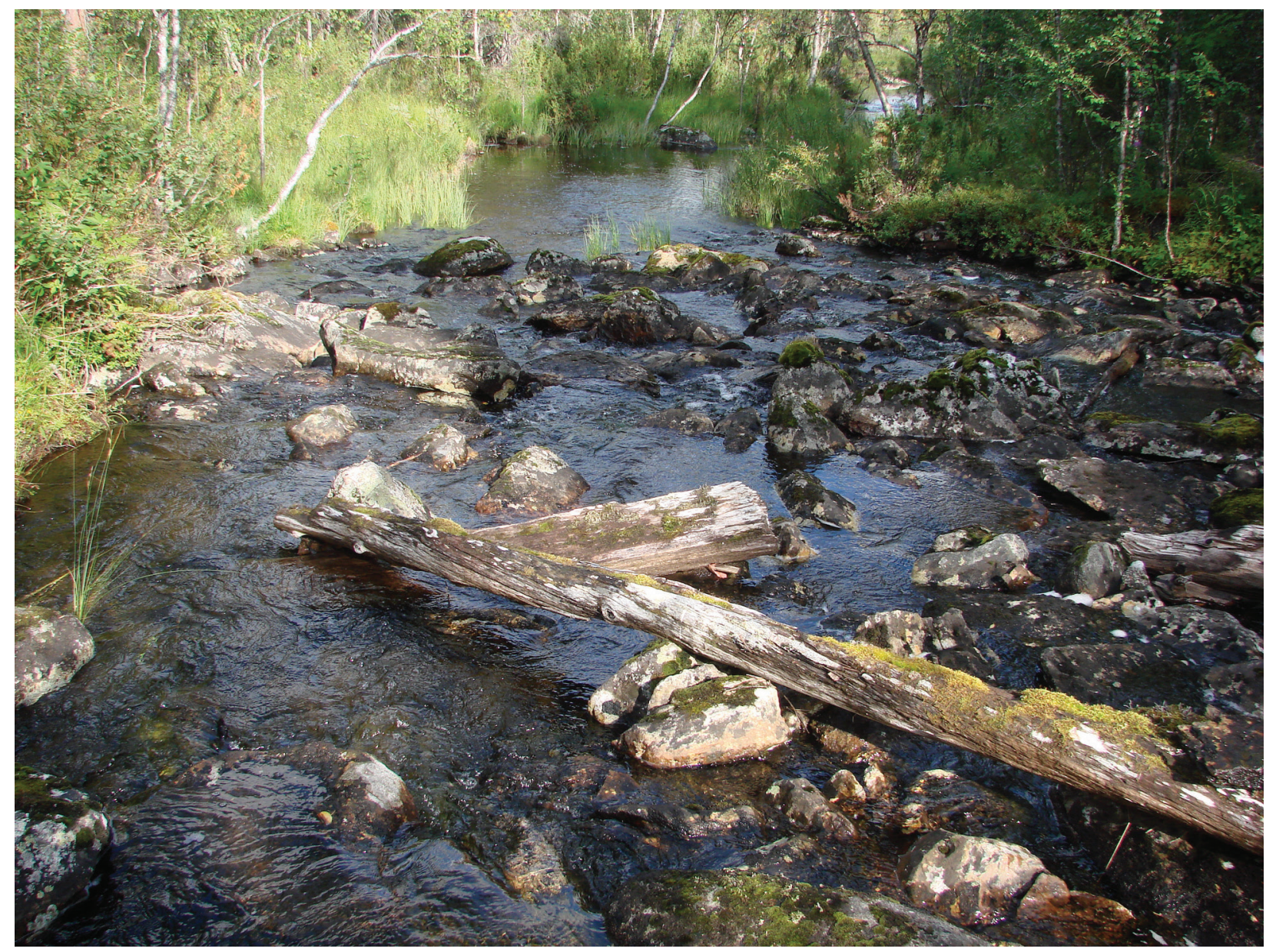

Fig. 1. Locality of Nephroma orvoi in the bed of a small unnamed stream, neighborhoods of Fedorova Tundra Mt., Murmansk Region (Photo: G. P. Urbanavichus). 
The identification of the triterpenoids was performed in accordance with the works of James et White (1987) and Timdal et al. (2020). The coordinates are in WGS84 geographic coordinate system. The studied specimens are deposited in the herbarium of the Institute of North Industrial Ecology Problems
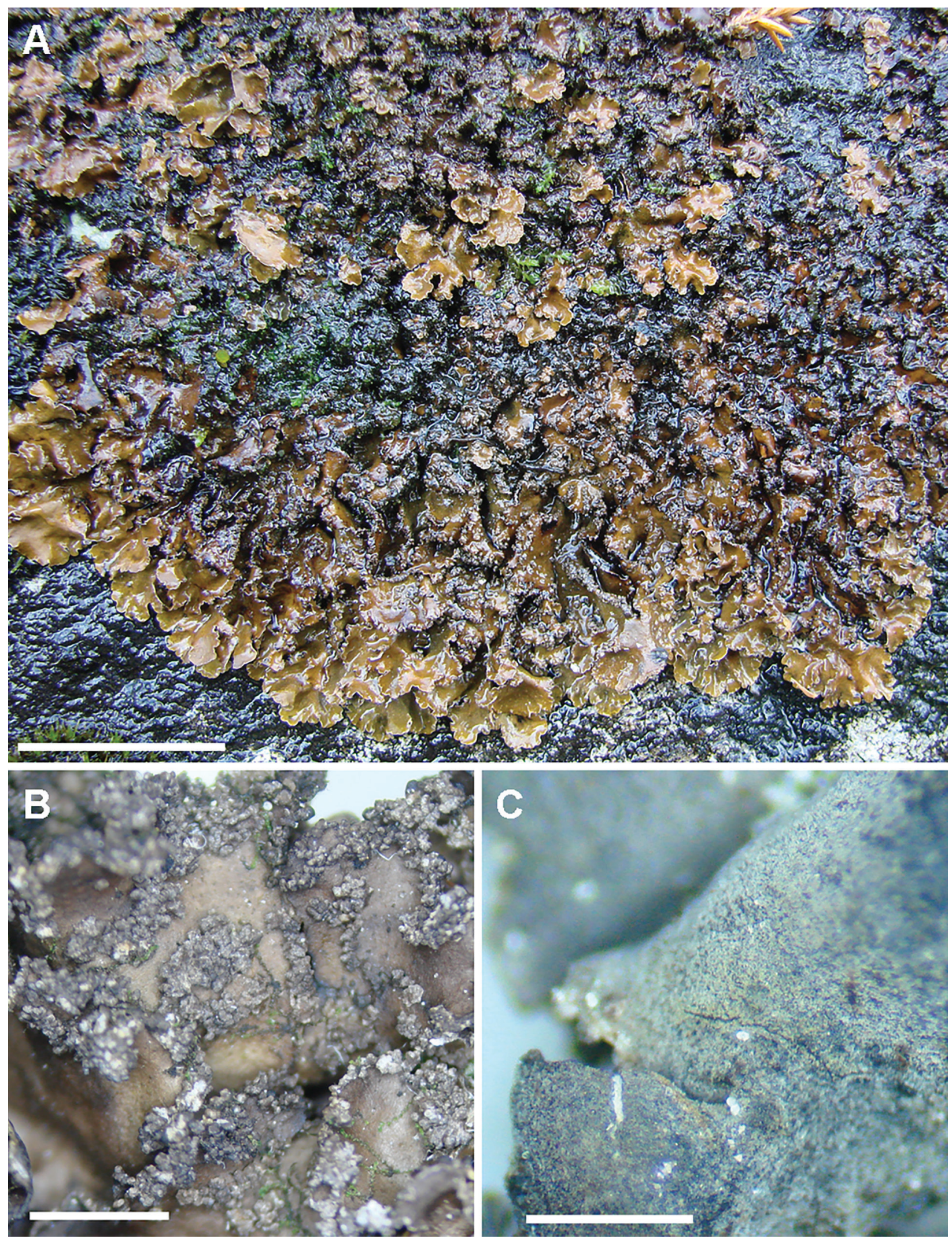

Fig. 2. Nephroma orvoi. A: Thallus on wet rock in the stream bed. Scale bar $=2 \mathrm{~cm}$. B: Lobes with granular corticate soredia. Scale bar $=5 \mathrm{~mm}$. C. Pseudotomentose lower surface. Scale bar $=2 \mathrm{~mm}$ (Photo: G. P. Urbanavichus). 
(INEP), duplicates are in the herbarium of the Altai State University (ALTB) and in the lichen herbarium of the Komarov Botanical Institute (LE).

\section{Results and Discussion}

Nephroma orvoi Timdal, M. Westb., Haugan, Hofton, Holien, Speed, Tønsberg et Bendiksby, 2020, Graphis Scripta 32(4): 78 (Fig. 2).

Thallus foliose, sufficiently firmly attached, forming rosettes up to $10(-15) \mathrm{cm}$ in diam. Lobes rounded, ascending margin entire, up to $1(-1.5) \mathrm{cm}$ wide; upper surface medium brown to dark brown or partly olivaceous brown, smooth to distinctly faveolate especially near the lobe ends, with mostly laminal, more rarely marginal, soralia which are often concentrated on the ridges; soredia granular, long remaining corticate, sometimes forming coralloid clusters; medulla white; lower surface darker brown to blackish brown in inner part, medium brown near the margins, smooth, pseudotomentose in middle and inner part, naked or pseudotomentose near the lobe ends. Apothecia and conidiomata not seen. Photobiont Nostoc.

Secondary metabolites: $7 \beta$-acetoxyhopan-22ol (T1), hopane-6 $\alpha, 22$-diol (T3), hopane-7 $\beta, 22$-diol (T4) and hopane-6 $\alpha, 7 \beta, 22$-triol (T6), with traces of additional unknown terpenoids.

Material examined: "Russia, Murmansk Region, Pechenga District, Pasvik Nature Reserve, Khokokoski rapids on the Paz River, alt. $35 \mathrm{~m}$, on rock outcrops in open habitat on the right bank of the Paz River. $69^{\circ} 22^{\prime} 26.5^{\prime \prime} \mathrm{N}, 29^{\circ} 42^{\prime} 07.5^{\prime \prime} \mathrm{E} .26$ VII 2014. G. P. Urbanavichus" (INEP). "Russia, Murmansk Region, Lovosero District, NE of Fedorova Tundra Mt., rapids on a small unnamed stream, alt. $210 \mathrm{~m}$, on rocks in the bed of stream. $67^{\circ} 29^{\prime} 28.2^{\prime \prime} \mathrm{N}, 35^{\circ} 04^{\prime} 01.1^{\prime \prime}$ E. 11 VIII 2021. G. P. Urbanavichus" (ALTB, INEP, LE).
The species is morphologically very similar to $N$. parile, and the diagnostic morphological differences may not always lead to definite identification. However, $N$. parile has mostly bluish and 'soft' soredia and contains other lichen substances (Timdal et al., 2020). TLC is required for definite identification. A morphologically rather similar species, N. isidiosum (Nyl.) Gyeln., differs morphologically mainly in forming terete or coralloid isidia and in forming a more distinct (longer) tomentum than the short pseudotomentum of $N$. orvoi.

In Fennoscandia, N. orvoi occured exclusively in boreal to arctic-alpine habitats and its distribution is northern boreal-subalpine with a northeastern boreo-continental tendency, whereas $N$. parile also occurred in nemoral and hemiboreal (boreonemoral) habitats (Timdal et al., 2020). The locality in the Pasvik Nature Reserve is $11 \mathrm{~km}$ east of the nearest known location in the Finnmark, Norway - "SørVaranger, Pasvik, Kiltjørnan" (Timdal et al., 2020). Probably, this species can have a wide distribution throughout Northern Eurasia. Further revision of old collections in herbaria and explorations in arcticboreal areas are needed to clarify the distribution in Russia.

\section{Acknowledgements}

The work of G. P. Urbanavichus was carried out within the framework of the State Research Program of the Kola Science Centre of RAS no. AAAA-A18-118021490070-5. The study by I. N. Urbanavichene was carried out within the framework of the institutional research project ("Herbarium collections of BIN RAS (history, conservation, investigation and replenishment)") of the Komarov Botanical Institute of the Russian Academy of Sciences ((№ AAAA-A18-118022090078-2).

\section{References}

James P. W., White F. J. 1987. Studies on the genus Nephroma I. The European and Macaronesian species. The Lichenologist 19: 215-268. DOI: 10.1017/S0024282987000239

Orange A., James P. W., White F. J. 2001. Microchemical methods for the identification of lichens. London: British Lichen Society. $101 \mathrm{pp}$.

Timdal E., Westberg M., Haugan R., Hofton T. H., Holien H., Speed J. D. M., Tonsberg T., Bendiksby M. 2020. Integrative taxonomy reveals a new species, Nephroma orvoi, in the $N$. parile species complex (lichenized Ascomycota). Graphis Scripta 32(4): 70-85.

Vitikainen O. 2007. Nephromataceae. In: Nordic Lichen Flora. Vol. 3. T. Ahti, P. M. Jørgensen, H. Kristinsson, R. Moberg, U. Søchting, G. Thor (eds). Uppsala: Nordic Lichen Society. Pp. 91-95. 